\title{
PERANCANGAN APLIKASI RAWAT JALAN PADA UNIT PELAKSANA TEKNIS DINAS (UPTD) KESEHATAN BENAI
}

\author{
Harianja \\ Fakultas Teknik, Universitas Islam Kuantan Singingi \\ J1. Gatot Subroto KM.7 Jake teluk Kuantan Riau \\ Email : harianja@uniks.ac.id
}

\begin{abstract}
Abstrak
Unit pelaksana teknis dinas kesehatan merupakan ujung tombak dari pelayanan pemerintah di bidang kesehatan masyarakat. Karena itu proses pelayanan di tingkat ini harus benar-benar efektif dan efisien, sehingga cita - cita mewujudkan masyarakat Indonesia yang sehat dapat diwujudkan. Untuk mewujudkan pelayanan yang efektif dan efisien salah satunya dapat dilakukan dengan cara menerapkan aplikasi berbasis komputer. Penelitian ini bertujuan untuk merancang aplikasi berbasis komputer agar proses pelayanan registrasi pasien, pendataan dan pelaporan menjadi lebih mudah.
\end{abstract}

Kata Kunci : UPTD Kesehatan, aplikasi komputer, registrasi pasien

\section{PENDAHULUAN}

Unit pelaksana teknis dinas kesehatan (PUSKESMAS) merupakan salah satu sarana pemerintah dalam usaha meningkatkan kesehatan masyarakat. Unit ini memiliki kegiatan manajemen dalam melaksanakan fungsinya seperti pengelolaan data perawatan, pengelolaan obat, pengelolaan data pegawai dan lain sebagainya. Sesuai perkembangannya UPTD Kesehatan sekarang ini sudah melakukan dua macam perawatan yaitu rawat inap dan rawat jalan.

Unit Pelaksana Teknis Dinas Kesehatan Benai merupakan UPTD rawat jalan yang dalam kesehariannya melakukan berbagai macam kegiatan pengelolan data. Kegiatankegiatan rawat jalan yang dilakukan dalam UPTD kesehatan Benai meliputi:

1. Pendaftaran pasien yang meliputi nama pasien, alamat, umur, jenis kelamin tempat tanggal lahir, orang tua atau kepala keluarga. Setiap pasien yang mendaftar akan diberikan kartu pasien (kartu berobat) yang akan digunakan untuk melakukan proses pengobatan di UPTD kesehatan.

2. Mendata setiap pasien yang akan melakukan proses pengobatan dengan melihat kartu berobat dan mencocokkan dengan data yang ada pada UPTD kesehatan. Serta menanyakan keluhan-keluhan yang dialami pasien untuk dapat mengarahkan pasien pada bagian atau ruangan yang tepat.

3. Mencatat semua semua hasil pemeriksaan pasien seperti jenis penyakit, jenis obat, dokter atau tim medis yang melakukan pemeriksaan.

4. Membuat semua laporan yang meliputi laporan data rawat jalan perbulan berdasarkan kategori pasien (sesuai jenis asuransi pasien) untuk dilaporkan ke Dinas Kesehatan.

Kegiatan manajemen di atas memerlukan data dan informasi yang sangat banyak sehingga diperlukan penggunaan sebuah sistem komputer yang dapat mempermudah dalam pelaksanaannya. 


\section{TINJAUAN PUSTAKA}

\subsection{Unit Pelaksana Teknis Dinas Kesehatan (PUSKESMAS)}

Puskesmas adalah unit pelaksana teknis dinas kesehatan kabupaten/kota yang bertanggungjawab menyelenggarakan pembangunan kesehatan di suatu wilayah kerja. Sebagai unit pelaksana teknis dinas kesehatan kabupaten/kota (UPTD), puskesmas berperan menyelenggarakan sebagian dari tugas teknis operasional Dinas Kesehatan Kabupaten/Kota dan merupakan unit pelaksana tingkat pertama serta ujung tombak pembangunan kesehatan di Indonesia.

Pembangunan kesehatan adalah penyelenggaraan upaya kesehatan oleh bangsa Indonesia untuk meningkatkan kesadaran, kemauan dan kemampuan hidup sehat bagi setiap orang agar terwujud derajat kesehatan masyarakat yang optimal. Penanggungjawab utama penyelenggaraan seluruh upaya pembangunan kesehatan di wilayah kabupaten/kota adalah Dinas Kesehatan Kabupaten/Kota, sedangkan puskesmas bertanggungjawab hanya sebagian upaya pembangunan kesehatan yang dibebankan oleh dinas kesehatan kabupaten/kota sesuai dengan kemampuannya.

Secara nasional, standar wilayah kerja puskesmas adalah satu kecamatan, tetapi apabila di satu kecamatan terdapat lebih dari satu puskesmas, maka tanggungjawab wilayah kerja dibagi antar puskesmas, dengan memperhatikan keutuhan konsep wilayah (desa/kelurahan atau RW). Masing-masing puskesmas tersebut secara operasional bertanggungjawab langsung kepada Dinas Kesehatan Kabupaten/Kota.

Visi pembangunan kesehatan yang diselenggarakan oleh puskesmas adalah tercapainya Kecamatan Sehat menuju terwujudnya Indonesia Sehat. Kecamatan Sehat adalah gambaran masyarakat kecamatan masa depan yang ingin dicapai melalui pembangunan kesehatan, yakni masyarakat yang hidup dalam lingkungan dan berperilaku sehat, memiliki kemampuan untuk menjangkau pelayanan kesehatan yang bermutu secara adil dan merata serta memiliki derajat kesehatan yang setinggi-tingginya.

Indikator Kecamatan Sehat yang ingin dicapai mencakup 4 indikator utama yakni:

1. Lingkungan sehat

2. Perilaku sehat

3. Cakupan pelayanan kesehatan yang bermutu

4. Derajat kesehatan penduduk kecamatan

Rumusan visi untuk masing-masing puskesmas harus mengacu pada visi pembangunan kesehatan puskesmas di atas yakni terwujudnya Kecamatan Sehat, yang harus sesuai dengan situasi dan kondisi masyarakat serta wilayah kecamatan setempat.

Misi pembangunan kesehatan yang diselenggarakan oleh puskesmas adalah mendukung tercapainya misi pembangunan kesehatan nasional. Misi tersebut adalah:

Menggerakkan pembangunan berwawasan kesehatan di wilayah kerjanya. Puskesmas akan selalu menggerakkan pembangunan sektor lain yang diselenggarakan di wilayah kerjanya, agar memperhatikan aspek kesehatan, yakni pembangunan yang tidak menimbulkan dampak negatif terhadap kesehatan, setidak-tidaknya terhadap lingkungan dan perilaku masyarakat.

Mendorong kemandirian hidup sehat bagi keluarga dan masyarakat di wilayah kerjanya. Puskesmas akan selalu berupaya agar setiap keluarga dan masyarakat yang bertempat tinggal di wilayah kerjanya makin berdaya di bidang kesehatan, melalui peningkatan pengetahuan dan kemampuan menuju kemandirian untuk hidup sehat. 
Memelihara dan meningkatkan mutu, pemerataan dan keterjangkauan pelayanan kesehatan yang diselenggarakan. Puskesmas akan selalu berupaya menyelenggarakan pelayanan kesehatan yang sesuai dengan standar dan memuaskan masyarakat, mengupayakan pemerataan pelayanan kesehatan serta meningkatkan efisiensi pengelolaan dana sehingga dapat dijangkau oleh seluruh anggota masyarakat.

Memelihara dan meningkatkan kesehatan perorangan, keluarga dan masyarakat berserta lingkungannya. Puskesmas akan selalu berupaya memelihara dan meningkatkan kesehatan, mencegah dan menyembuhkan penyakit, serta memulihkan kesehatan perorangan, keluarga dan masyarakat yang berkunjung dan yang bertempat tinggal di wilayah kerjanya, tanpa diskriminasi dan dengan menerapkan kemajuan ilmu dan teknologi kesehatan yang sesuai. Upaya pemeliharaan dan peningkatan kesehatan yang dilakukan puskesmas mencakup pula aspek lingkungan dari yang bersangkutan.

\subsubsection{Sejarah Singkat UPTD Kesehatan Benai}

UPTD Kesehatan Benai merupakan sebuah usaha pemerintah yang bergerak dibidang pelayanan kesehatan. UPTD Kesehatan Benai mulai berdiri dan berfungsi pada tahun 1986. Pada awalnya UPTD Kesehatan Benai ini dinamakan dengan Puskesmas Benai dan pada tanggal 15 Februari 2012 nama tersebut diganti dengan Unit Pelaksana Teknis Dinas (UPTD) Kesehatan Benai yang dipimpin oleh dr. Nina Hardiani. UPTD Kesehatan Benai terletak di wilayah Kecamatan Benai Jl. KH. Agus Salim dan waktu itu mempunyai empat Puskesmas pembantu yaitu Beringin Jaya, Parit, Simandolak dan Pulau Kalimanting (sebelum pemekaran kecamatan atau sebelum terbentuknya Kecamatan Sentajo Raya) dengan jumlah seluruh karyawan 49 orang (dokter, bidan, perawat serta staf tata usaha)

\subsection{Alat Bantu Perancangan Sistem}

Langkah-langkah yang dilakukan pada tahap merancang suatu sistem dan program adalah membuat usulan pemecahan masalah secara logikal. Alat bantu yang digunakan antara lain adalah:

\subsubsection{Aliran Sistem Informasi (ASI)}

Aliran sistem informasi (ASI) merupakan dari semua dokumen maupun laporan serta tembusannya yang terjadi dalam proses pembuatan. Simbol-simbol yang digunakan aliran sistem informasi:

Tabel 2.1. Simbol-simbol Aliran Sistem Informasi (ASI)

\begin{tabular}{|l|l|}
\hline SIMBOL & KETERANGAN \\
\hline & $\begin{array}{l}\text { Dokumen. Simbol ini digunakan untuk } \\
\text { menggambarkan semua jenis dokumen, merupakan } \\
\text { formulir yang digunakan untuk merekam data } \\
\text { terjadinya suatu transaksi, yang menunjukkan input dan } \\
\text { output baik untuk proses manual, mekanik, atau } \\
\text { komputer. }\end{array}$ \\
\hline \hline $\begin{array}{l}\text { Proses Manual. Simbol ini digunakan untuk } \\
\text { menggambarkan kegiatan manual atau pekerjaan yang } \\
\text { dilakukan tanpa menggunakan komputer. Uraian } \\
\text { singkat kegiatan manual dicantumkan di dalam simbol }\end{array}$ \\
\hline
\end{tabular}




\begin{tabular}{|l|l|}
\hline & ini. \\
\hline & $\begin{array}{l}\text { Proses Komputer / Online Computer Process. } \\
\text { Simbol ini menggambarkan kegiatan proses dari } \\
\text { pegolahan data dengan komputer secara online. Uraian } \\
\text { singkat tentang operasi program komputer ditulis di } \\
\text { dalam simbol. }\end{array}$ \\
\hline & $\begin{array}{l}\text { Arsip. Simbol ini digunakan untuk menggambarkan } \\
\text { file komputer / non komputer yang disimpan sebagai } \\
\text { arsip. Di dalam simbol ini bisa ditulis huruf F atau } \\
\text { huruf A. }\end{array}$ \\
\hline $\begin{array}{l}\text { Kondisi. Simbol ini menunjukkan perbandingan } \\
\text { pernyataan, penyelesaian data yang memberikan pilihan } \\
\text { untuk langkah selanjutnya. }\end{array}$ \\
\hline $\begin{array}{l}\text { Terminal. Simbol ini digunakan untuk menunjukkan } \\
\text { awal dan akhir suatu proses }\end{array}$ \\
\hline $\begin{array}{l}\text { Garis Alir. Simbol ini menunjukkan aliran/arah dari } \\
\text { proses pengolahan data. }\end{array}$ \\
\hline
\end{tabular}

\subsubsection{Context Diagram}

Context diagram adalah gambaran umum dari sistem organisasi yang menunjukan batasan sistem, entity eksternal yang berintegrasi dengan sistem dan adanya informasi yang mengalir diantara entity dan sistem.

Tabel 2.2. Simbol-simbol Context Diagram

\begin{tabular}{|c|c|c|}
\hline Simbol & Nama & Keterangan \\
\hline & Simbol proses & $\begin{array}{l}\text { Menunjukan kegiatan proses } \\
\text { dari operasi program } \\
\text { computer }\end{array}$ \\
\hline & Simbol dokumen & $\begin{array}{l}\text { Menunjukkan dokumen input } \\
\text { dan output baik untuk proses } \\
\text { manual, mekanik atau } \\
\text { computer }\end{array}$ \\
\hline & $\begin{array}{l}\text { Simbol kegiatan } \\
\text { manual }\end{array}$ & $\begin{array}{ll}\text { Menunjukan kegiatan } \\
\text { manual }\end{array}$ \\
\hline & $\begin{array}{l}\text { Simbol } \\
\text { penyimpanan } \\
\text { arsip }\end{array}$ & $\begin{array}{l}\text { File yang diarsipkan menurut } \\
\text { alphabet atau huruf }\end{array}$ \\
\hline
\end{tabular}




\begin{tabular}{|l|l|l|}
\hline N & $\begin{array}{l}\text { Simbol } \\
\text { penyimpanan } \\
\text { arsip }\end{array}$ & $\begin{array}{l}\text { File yang diarsipkan menurut } \\
\text { numerik atau angka }\end{array}$ \\
\hline$\checkmark$ & Simbol garis alir & Menunjukan arus dari proses \\
\hline
\end{tabular}

\subsubsection{Data Flow Diagram (DFD)}

DFD menggambarkan sistem yang sedang berjalan dan diusulkan secara logika tanpa mempertimbangkan lingkungan fisik data. DFD memiliki beberapa simbol yang dapat dilihat pada tabel 2.3. yaitu sebagai berikut :

Tabel 2.3. Simbol-simbol Data Flow Diagram (DFD)

\begin{tabular}{|c|c|}
\hline SIMBOL & KETERANGAN \\
\hline & $\begin{array}{l}\text { Kesatuan Luar / External Entity. Merupakan } \\
\text { sumber/tujuan data atau suatu bagian/orang yang } \\
\text { berada diluar sistem tapi berhubungan dengan sistem } \\
\text { tersebut, baik itu memasukkan data maupun } \\
\text { mengambil data dari sistem. }\end{array}$ \\
\hline & $\begin{array}{l}\text { Proses. Simbol ini digunakan untuk melakukan } \\
\text { proses pengolahan data di dalam DFD, yang } \\
\text { menunjukkan suatu kegiatan yang mengubah aliran } \\
\text { data masuk (input) menjadi aliran data keluar } \\
\text { (output). }\end{array}$ \\
\hline & $\begin{array}{l}\text { Penyimpanan Data / Data Store. Berfungsi sebagai } \\
\text { tempat penyimpanan dokumen-dokumen/file-file } \\
\text { yang dibutuhkan dalam suatu sistem informasi. }\end{array}$ \\
\hline & $\begin{array}{l}\text { Aliran Data. Menunjukkan arus dalam proses, } \\
\text { dimana simbol aliran data ini mempunyai nama } \\
\text { tersendiri. }\end{array}$ \\
\hline
\end{tabular}

\section{.2.4. Entity Relationship diagram (ERD)}

Entity relationship diagram digunakan untuk merancang database. ERD menggambarkan hubungan antara file-file yang ada. Adapun simbol-simbol yang terdapat dalam ERD dapat kita lihat pada tabel 2.4. yaitu sebagai berikut :

Tabel 2.4. Simbol-simbol Entity Relationship Diagram (ERD) 


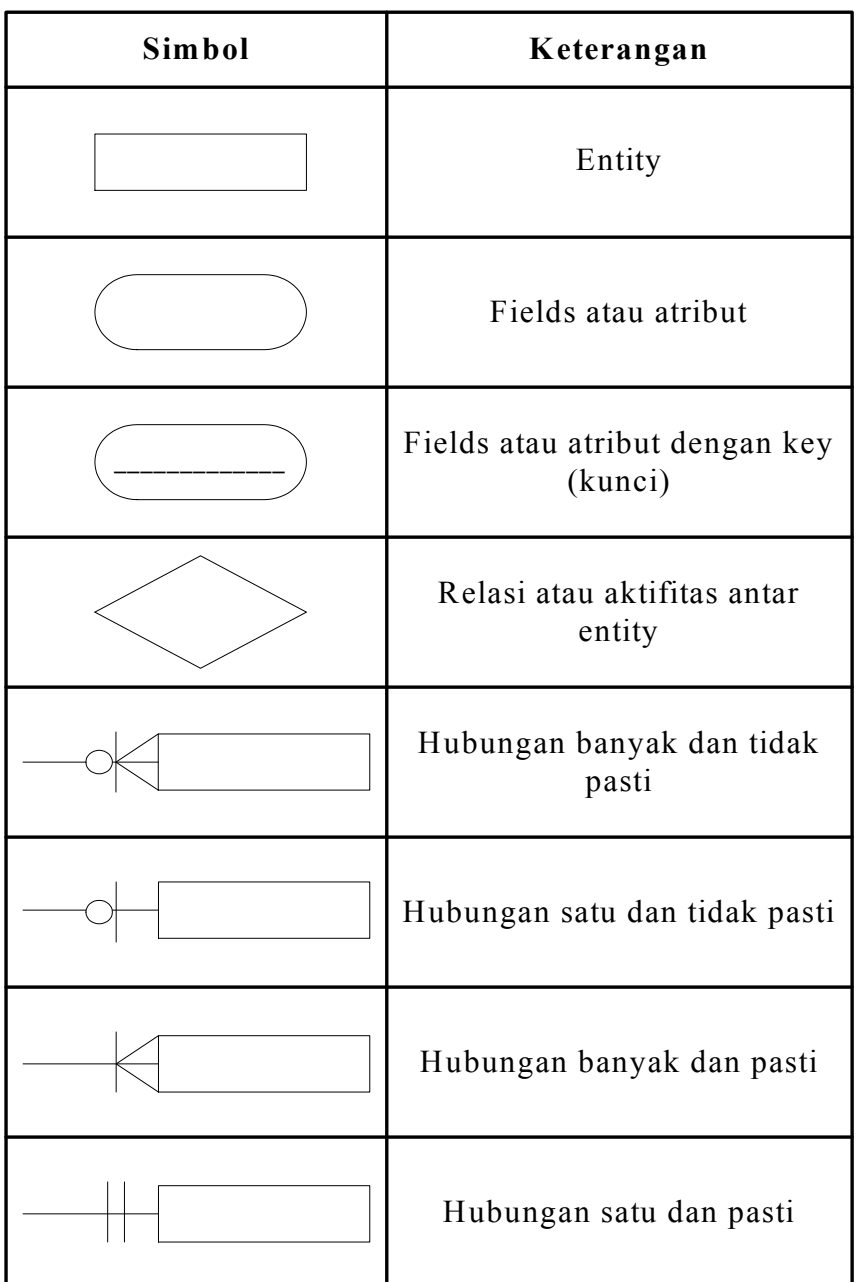

\subsection{Konsep Dasar Database}

Sebelum memulai mendesain dan membangun database dengan menggunakan program aplikasi database Ms. Access, terlebih dahulu kita harus lebih mengenal lagi apa yang dimaksud dengan database.

\subsubsection{Pengertian Database}

Database (basis data) adalah kumpulan file-file yang mempunyai kaitan antara satu file dengan file yang lain sehingga membentuk data untuk menginformasikan satu perusahaan dan instansi. Bila terdapat file yang tidak dapat dipadukan atau dihubungkan dengan file yang lainnya, berarti file tersebut bukanlah kelompok dari satu database, melainkan membentuk satu database sendiri. Database juga merupakan landasan bagi pembuatan dan pengembangan program aplikasi. Oleh sebab itu, database harus dibuat sedemikian rupa sehingga pembuatan program lebih mudah dan cepat.

Database merupakan salah satu komponen yang penting dalam sistem informasi, karena merupakan basis dalam menyediakan informasi bagi para pemakai. Database terdiri dari data yang akan digunakan atau diperuntukkan terhadap banyak user, dari masing-masing user akan menggunakan data tersebut sesuai dengan tugas dan fungsinya.

Beberapa Definisi tentang Database :

1. Menurut Gordon C. Everest :

Database adalah koleksi atau kumpulan data yang mekanis, terbagi / shared, terdefinisi secara formal dan dikontrol terpusat pada organisasi. 
2. Menurut C.J. Date :

Database adalah koleksi "data operasional" yang tersimpan dan dipakai oleh sistem aplikasi dari suatu organisasi.

a. Data input adalah data yang masuk dari luar sistem

b. Data output adalah data yang dihasilkan sistem

c. Data operasional adalah data yang tersimpan pada sistem

3. Menurut Toni Fabbri :

Database adalah sebuah sistem file-file yang terintegrasi yang mempunyai minimal primary key untuk pengulangan data.

4. Menurut S. Attre :

Database adalah koleksi data-data yang saling berhubungan mengenai suatu organisasi / enterprise dengan macam-macam pemakaiannya.

Definisi Dasar Struktur Database :

a. Data: Sekumpulan fakta mengenai objek tertentu, orang dan lain-lain yang dinyatakan dengan angka, huruf, gambar, film, suara dan sebagainya yang relevan dan belum mempunyai arti.

b. Informasi: Hasil pengolahan data yang konkrit dan sudah mempunyai arti untuk mencapai suatu tujuan tertentu.

c. Tabel: Merupakan hal yang paling mendasar dalam hal penyimpanan data yang terdiri dari field dan record.

d. Field (kolom): Merupakan elemen dari tabel yang berisikan informasi tertentu yang spesifik tentang subjudul tabel pada sebuah item data.

Syarat-syarat pembentukan Field Name pada tabel:

a) Harus Unik atau Spesifik

b) Boleh disingkat

c) Pemisah sebagai pengganti spasi dalam pembentuk field adalah tanda lambang ".". Contoh:

Kode Barang menjadi KdBarang, KodeBrg, Kd_Brg, Kd_Barang.

e. Record (baris): Sekumpulan data yang saling berkaitan tentang sebuah subjek tertentu, misalnya data seorang siswa akan disimpan dalam record yang terdiri dari beberapa kolom / field.

\section{METODE PENELITIAN}

Penelitian ini diawali dengan identifikasi masalah dan kajian literatur yang berhubungan dengan bidang kajian yaitu tentang Unit Pelaksan Teknis Dinas Kesehatan, Data base, alat bantu perancangan sistem dan aplikasi yang digunakan. Kemudian dilanjutkan dengan tahapan analisa dan perancangan sistem. Setelah perancangan sistem selesai, dilakukan evaluasi terhadap sistem yang dibuat untuk mengetahui kelemahan atau kekurangan yang masih ada. Jika sistem dianggap masih kurang baik, kembali dilakukan perbaikan pada tahap perancangan, jika sistem sudah dianggap baik dilanjutkan dengan tahap pembuatan laporan. Adapun diagram alir penelitian ini dapat dilihat pada gambar berikut: 


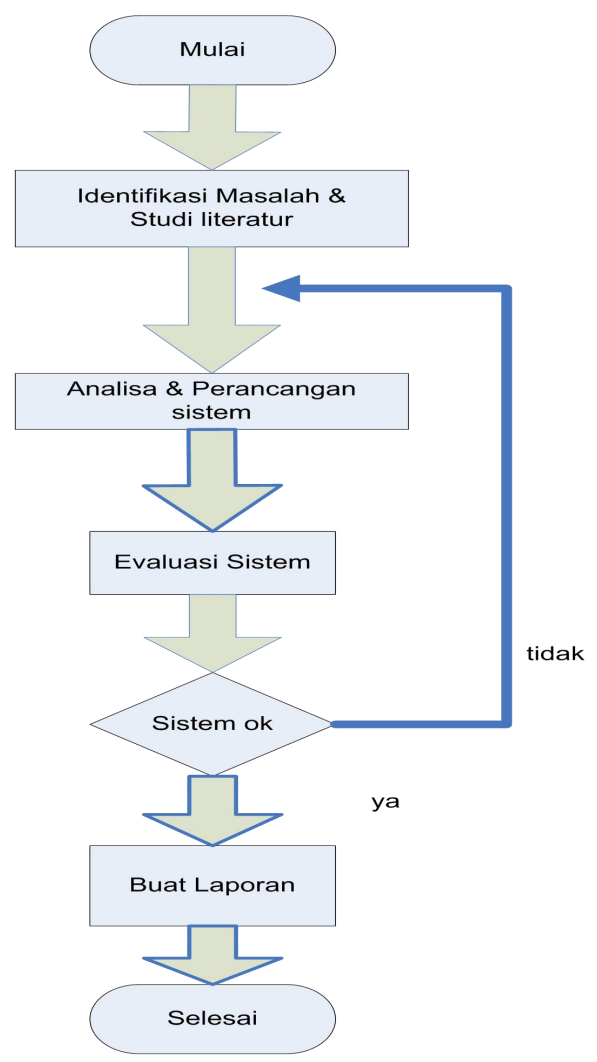

Gambar 3.1. Diagram Alir Penelitian

\section{HASIL DAN PEMBAHASAN}

Berikut ini adalah ringkasan dari hasil penelitian tentang Perancangan Aplikasi Rawat Jalan Pada Unit Pelaksana Teknis Dinas (UPTD) Keseahatan Benai.

\section{A. Halaman Login}

Untuk memasuki sistem atau aplikasi ini kita harus masuk dulu ke halaman login, dimana kita diminta untuk memasukkan nama pengguna dan kata sandi. Jika login sukses akan muncul halaman menu utama aplikasi rawat jalan UPTD Kesehatan Benai. Jika gagal sistem akan memberikan kesempatan sampai tiga kali kepada kita untuk mengulangi. Jika masih salah sistem akan menganggap kita sebagai pengguna ilegal. 


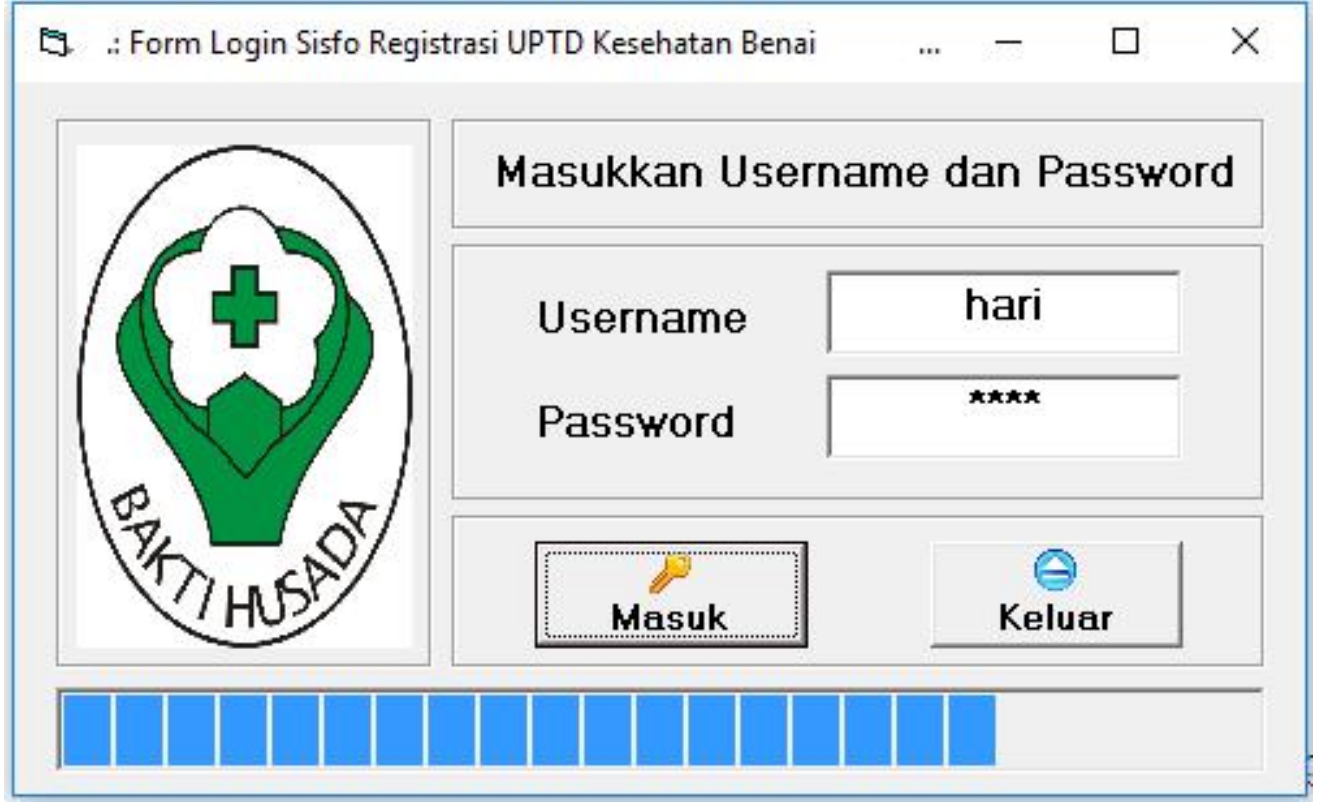

Gambar 4.1. Halaman Login Sistem

\section{B. Tampilan Menu Utama}

Pada halaman menu utama ini terdapat 3 kelompok menu yaitu: input data awal, registrasi dan laporan. Pada bagian input data awal terdapat dua menu yaitu no rekam medis dan data pasien, pada bagian registrasi terdapat menu rawat jalan sedangkan pada bagian laporan terdapat pilihan menu laporan tahunan, laporan bulanan, laporan kategori, laproan rekam medis dan laporan data pasien. Kita dapat dengan bebas memilih menu sesuai keinginan pada bagian ini. Selain itu kita juga dapat memilih menu pada bagian menu yang ada pada bagian kiri atas.

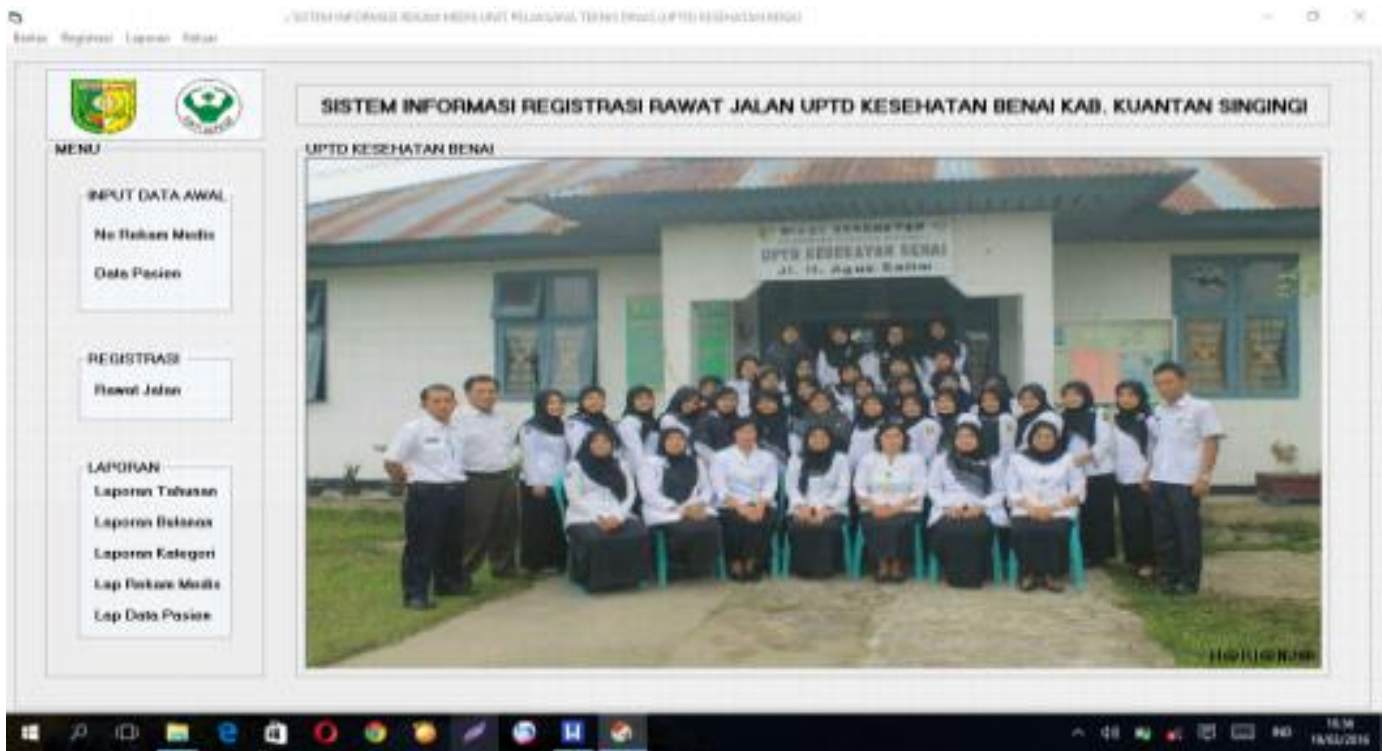

Gambar 4.2. Halaman Menu Utama 
Menu No. Rekam Medis digunakan untuk membuka form rekam medis, menu data pasien untuk membuka form data pasien, menu rawat jalan digunakan untuk membuka form registras rawat jalan, menu laporan tahunan digunakan untuk membuka laporan tahunan, menu laporan bulanan digunakan untuk membuka laporan bulanan dan seterusnya.

\section{Form No Rekam Medis}

Halaman menu rekam medis dapat dibuka dengan mengklik menu No Rekam Medis yang ada pada halaman menu utama sistem. Halaman ini digunakan untuk memasukkan data rekam medis pasien dan merupakan data awal yang harus dimasukkan ke dalam sistem. Data rekam medis ini merupakan data tempat semua data pasien bernaung. Data ini biasanya berisi data kepala keluarga yang akan menaungi setiap data pasien. Jadi tidak ada pasien yang tidak mempunyai data rekam medis yang artinya pasien tidak bisa didaftarkan ke dalam sistem jika data rekam medisnya belum ada. Adapun bentuk dari form data rekam medis terlihat pada gambar berkut.

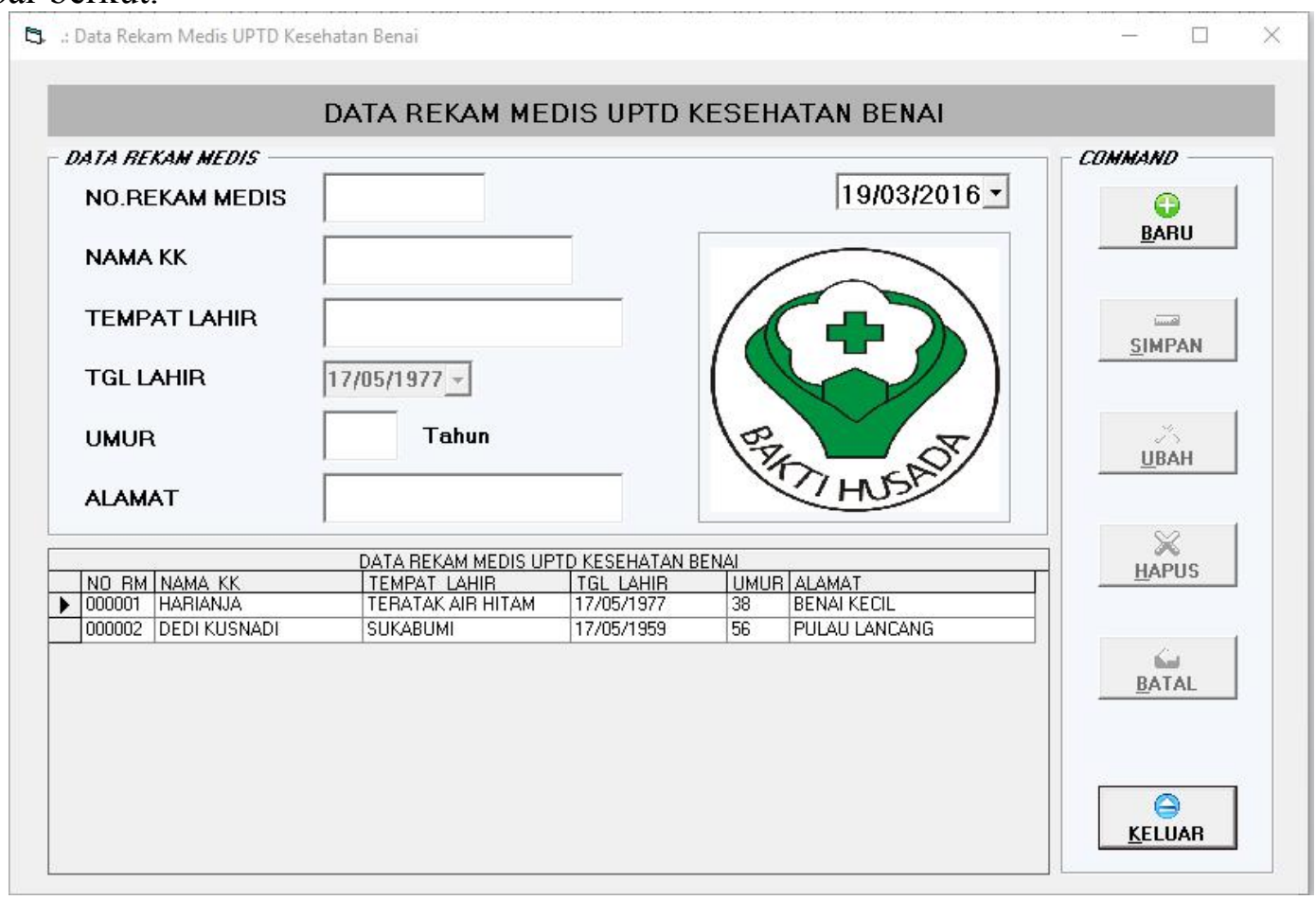

Gambar 4.3. Tampilan Halaman No Rekam Medis

Pada gambar di atas terlihat bahwa ada beberapa kolom isian yang harus diisi seperti No Rekam Medis, Nama Kepala Keluarga (KK), Tempat Lahir Kepala Keluarga, Tangal Lahir Kepala Keluarga, Umur Kepala Keluarga (bersifat otomatis) dan Alamat Kepala Keluarga. Isian ini sesuai dengan format lama yang ada pada Unit Pelaksana Teknis Dinas Kesehatan Benai.

\section{Form Data Pasien}

Form data pasien digunakan untuk mengentrikan data pasien. Form ini baru bisa dientrikan data secara sempurna ketika form no rekam medis sudah diisi. Hal ini disebabkan pada form data pasien dibutuhkan data no rekam medis yang diambil dari tabel rekam medis. Untuk membuka form data pasien kita dapat mengklik menu data pasien dan tampilannya terlihat sebagai berikut. 


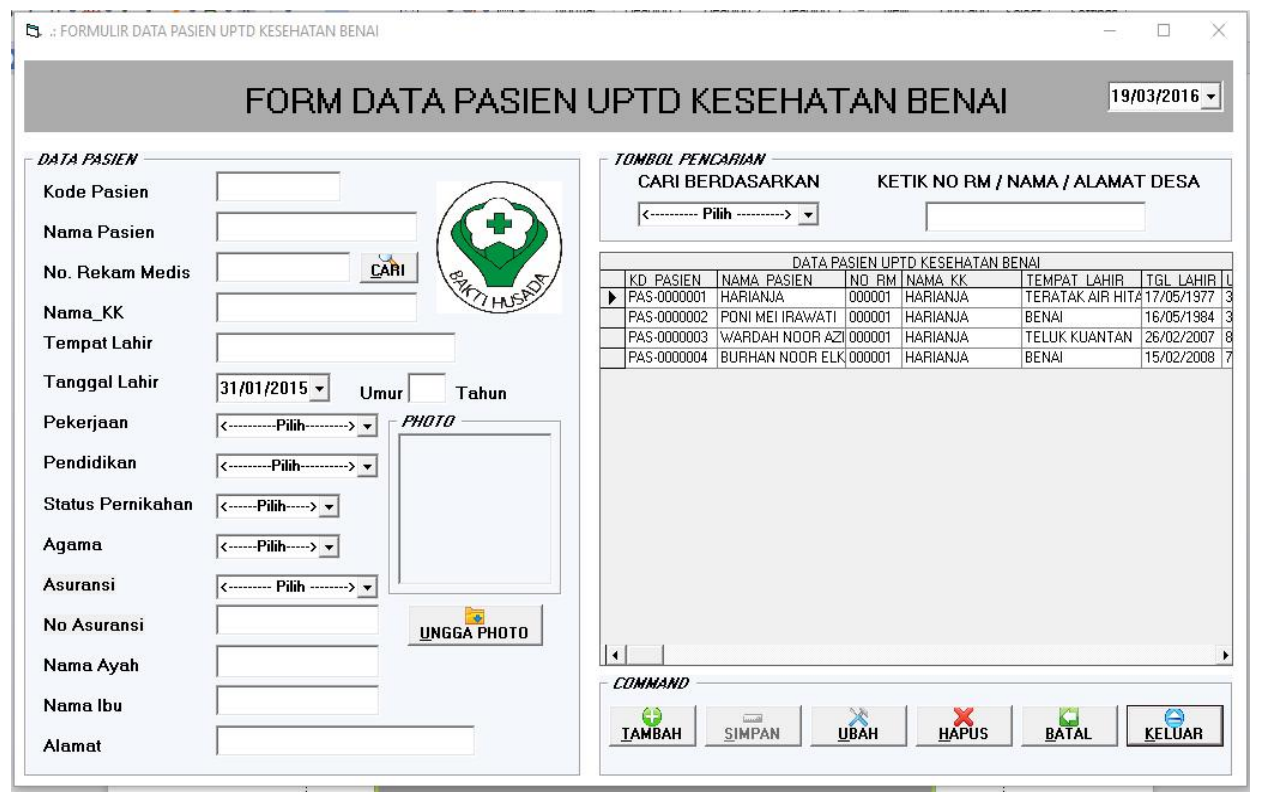

Gambar 4.4. Tampilan Halaman Simulasi Gerbang Not (Inverter)

Pada form data pasien di atas terlihat bahwa data data yang harus diisikan adalah kode pasien, nama pasien, no rekam medis pasien, nama KK, tempat lahir pasien, tanggal lahir pasien, umur pasien (otomatis), pekerjaan, pendidikan, status pernikahan, agama, asuransi yang dipakai bagi pasien yang menggunakan asuransi, no asuransi, nama ayah, nama ibu, alamat pasien dan photo pasien (kalau ada).

\section{E. Form Registrasi Rawat Jalan}

Form registrasi rawat jalan merupakan form yang akan digunakan untuk mencatat proses rawat jalan (pengobatan) yang dilakukan oleh pasien. Jika pasien sudah pernah melakukan atau berobat di UPTD, maka petugas (piket) tidak perlu lagi untuk mengisi data rekam medis dan data pasien karena data mereka sudah terekam dengan baik di data base. Hal yang harus petugas lakukan adalah membuka form registrasi pasien ini untuk kemudian memasukkan kode pasien dan jenis layanan yang dipilih pasien. Form registrasi rawat jalan ini dirancang sesimpel mungkin agar prosesnya berjalan seefisien dan seefektif mungkin. Hal- hal yang perlu dilakukan petugas dapat dirinci sebagai berikut:

1. Klik menu rawat jalan pada halaman menu utama sehingga muncul halaman form registrasi rawat jalan. 


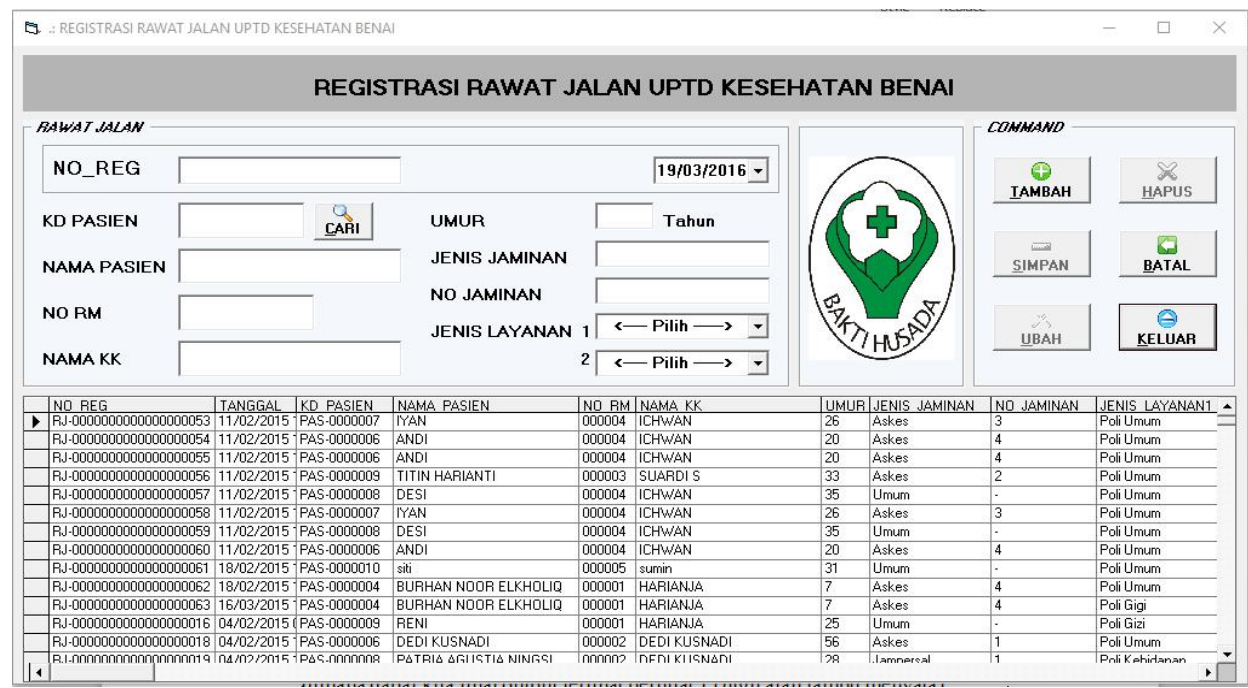

Gambar 4.5. Form Registrasi Rawat Jalan UPTDK Benai

2. Klik tombol tambah sehingga muncul no registrasi rawat jalan pasien secara otomatis.

3. Masukkan kode pasien. Kode pasien dapat diperoleh dengan bertanya langsung kepada pasien, atau dengan melihat kartu berobat pasien. Jika pasien tidak membawa kartu berobat, maka petugas dapat mencari kode pasien dengan cara mengklik tombol cari sehingga muncul form pencarian data pasien seperti gambar berikut.

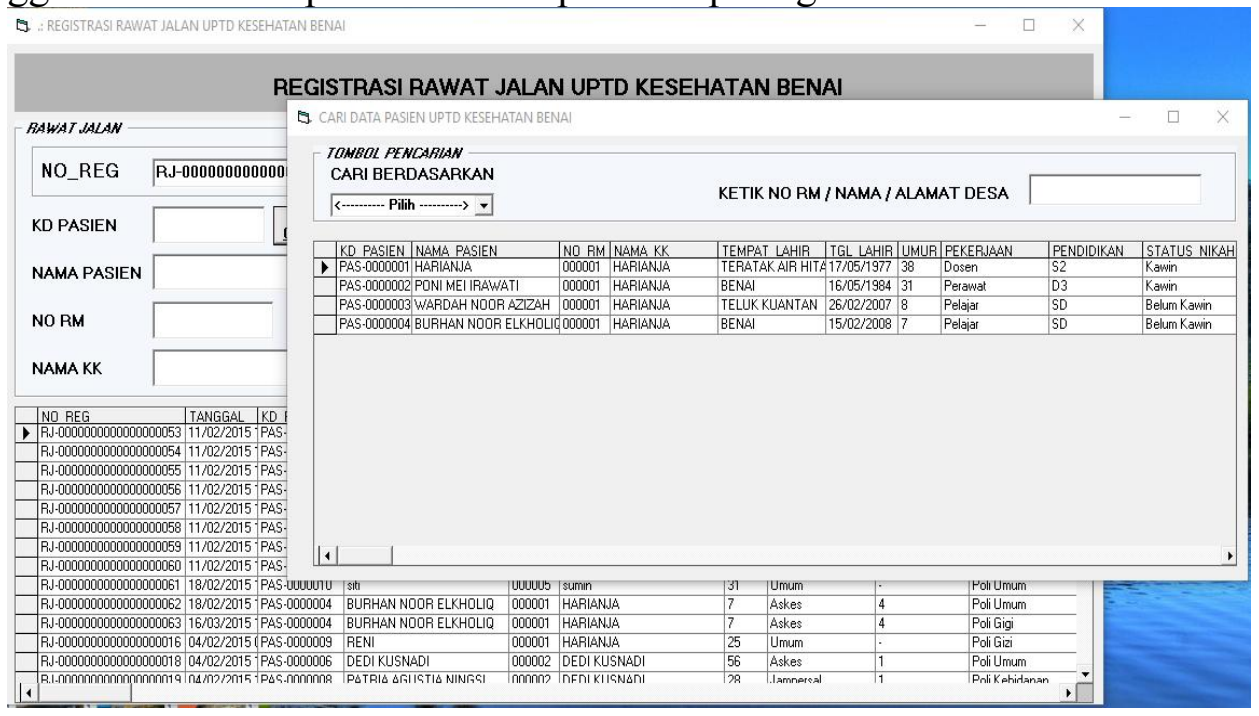

4. Setelah kode pasien sudah dimasukkan, maka petugas cukup memilih jenis layanan yang akan diberikan kepada pasien tersebut. Setelah itu lakukan penyimpanan.

\section{F. Form Cetak Laporan}

Jika kita kembali melihat pada tampilan Halaman Menu Utama, maka kita dapat melihat beberapa menu laporan seperti laporan tahunan, laporan bulanan, laporan perkategori, laporan rekam medis dan laporan data pasien. Laporan Tahunan digunakan untuk mencetak laporan registrasi rawat jalan pasien selama satu tahun, Laporan Bulanan untuk untuk melihat data registrasi rawat pasien dalam satu bulan, Laporan Kategori untuk melihat data registrasi rawat pasien berdasarkan kategori pasien seperti Jamkesmas, Umum, Jamkesda, Askes dan lain lain. Laporan rekam medis dan data pasien digunakan untuk melihat berapa jumlah data rekam medis dan data pasien yang terdaftar di UPTD Kesehatan Benai tersebut. 
Untuk melakukan cetak laporan kita harus memilih salah satu menu laporan yang diinginkan sehingga muncul form cetak laporan seperti gambar berikut.

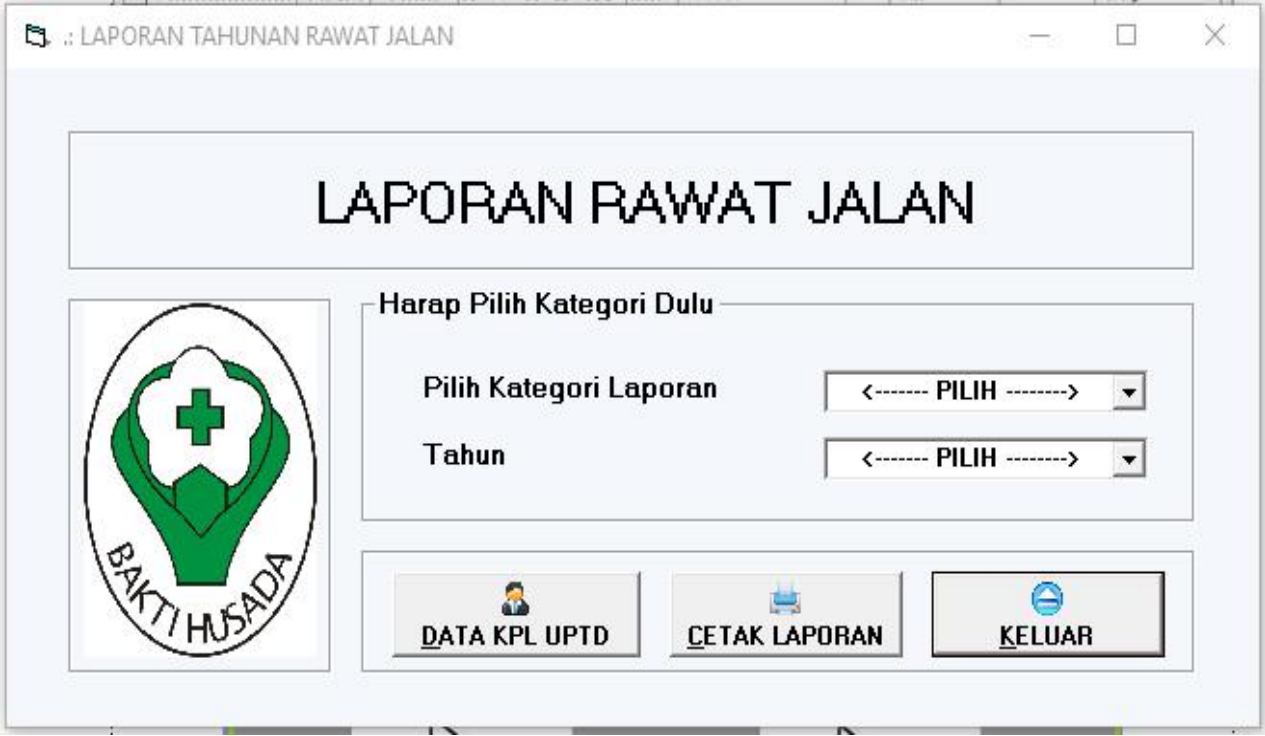

Gambar 4.6. Form Cetak Laporan Tahunan

Gambar di atas merupakan form cetak laporan untuk data perawatan selama satu tahun. Sebelum melakukan cetak laporan petugas harus melakukan beberapa hal terlebih dahulu seperti memilih kategori laporan (Umum, Askes, Jamkesda, Jampersal dan lain lain) seperti terlihat pada gambar berikut.

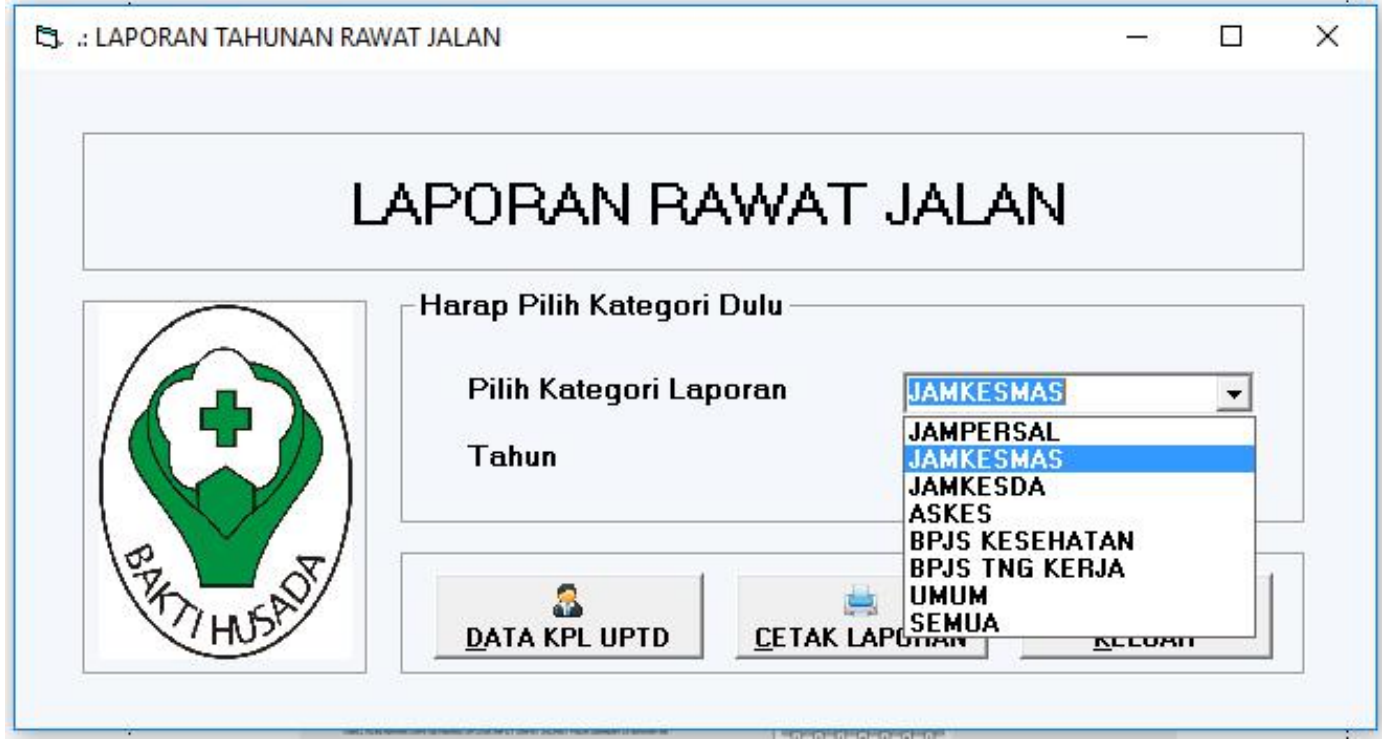

Gambar 4.7. Form Cetak Laporan Tahunan

Setelah selesai menentukan kategori dan tahun, petugas harus memilih tombol Data Kepala UPTD untuk mengisi data kepala UPTD sehingga secara otomatis tertulis di laporan. Berikut ini merupakan tampilan form untuk memasukkan Data Kepala UPTD. 


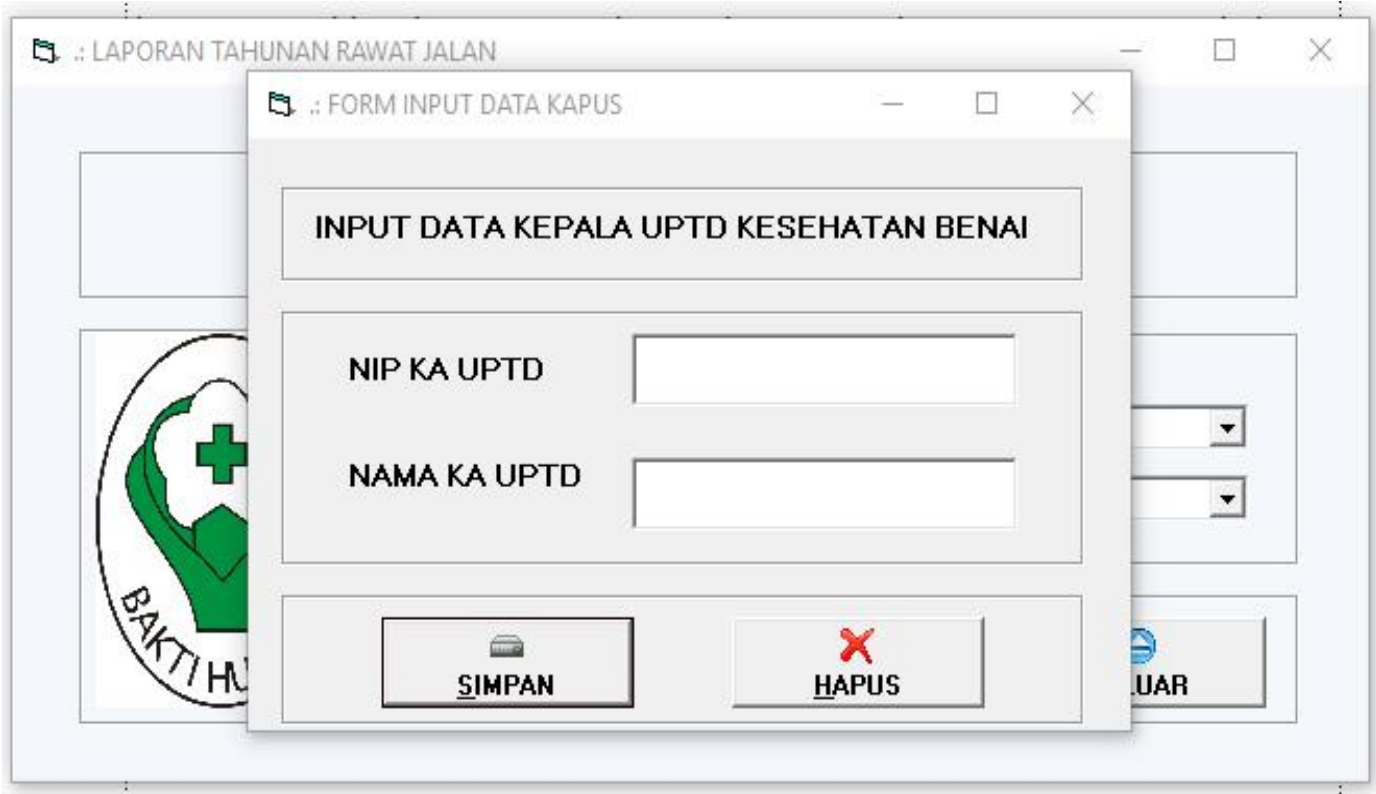

Gambar 4.8. Form Entri Data Kepala UPTD

Setelah memasukkan nama dan NIP kepala UPTD lakukan penyimpanan dengan menekan tombol save. Data yang diisikan ini akan muncul di laporan pada bagian tanda tangan sehingga tidak perlu lagi untuk menuliskan nama dan NIP secara manual (dengan pena) pada bagian ini. Jadi jika suatu saat kepala UPTD tidak ada di tempat atau ada pergantian kepala UPTD, laporan tetap bisa ditanda tangani oleh penggantinya.

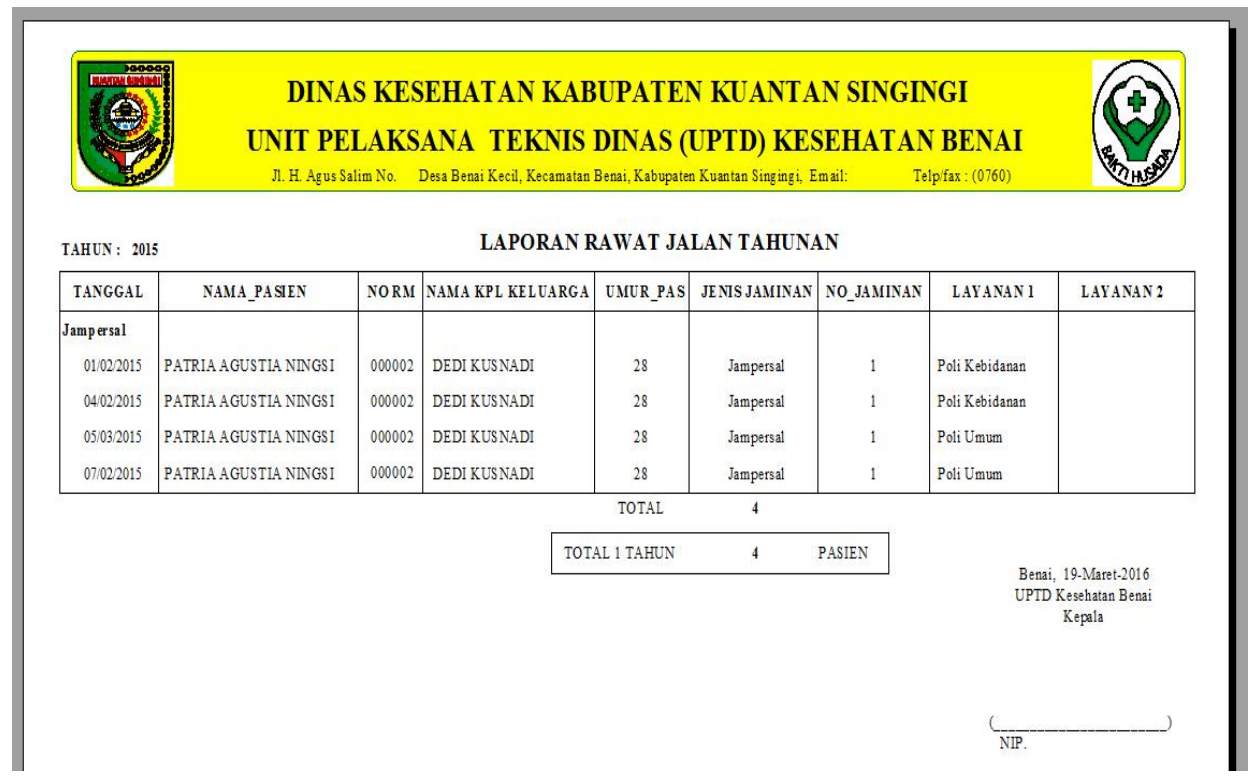

Gambar 4.9. Laporan Rawat Jalan Tahunan

Selain laporan rawat jalan tahunan, pada aplikasi ini juga tersedia pilihan untuk membuat laporan rawat jalan perbulan, laporan rawat jalan pertanggal atau perhari, laporan rawat jalan perkategori, laporan data rekam medis dan laporan data pasien. Berikut ini merupakan bentuk dari masing - masing laporan tersebut. 
1. Laporan Data Rawat Jalan Bulanan
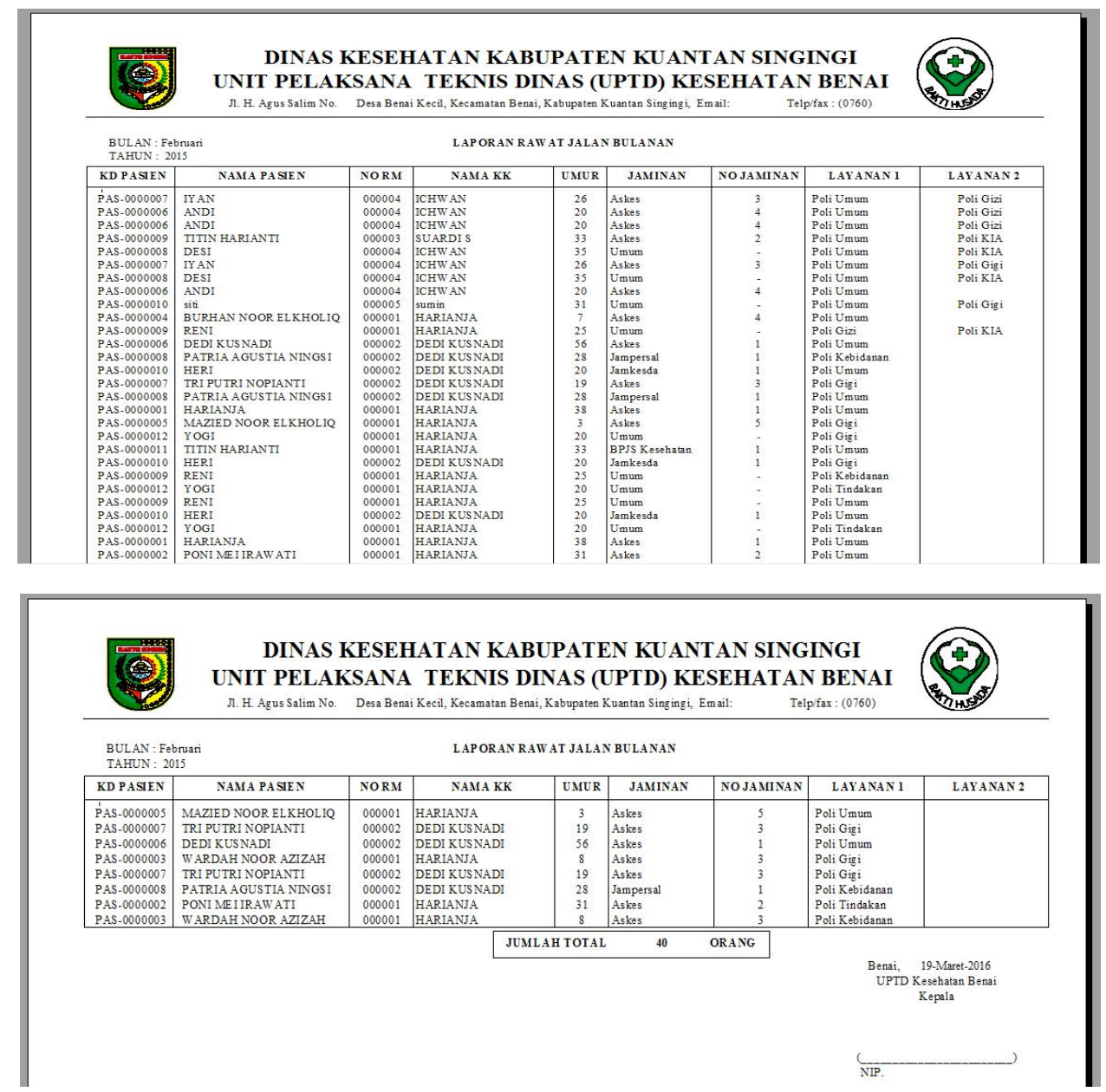

Gambar 4.10. Laporan Rawat Jalan Bulanan

2. Laporan Data Rawat Jalan Pertanggal (Harian)

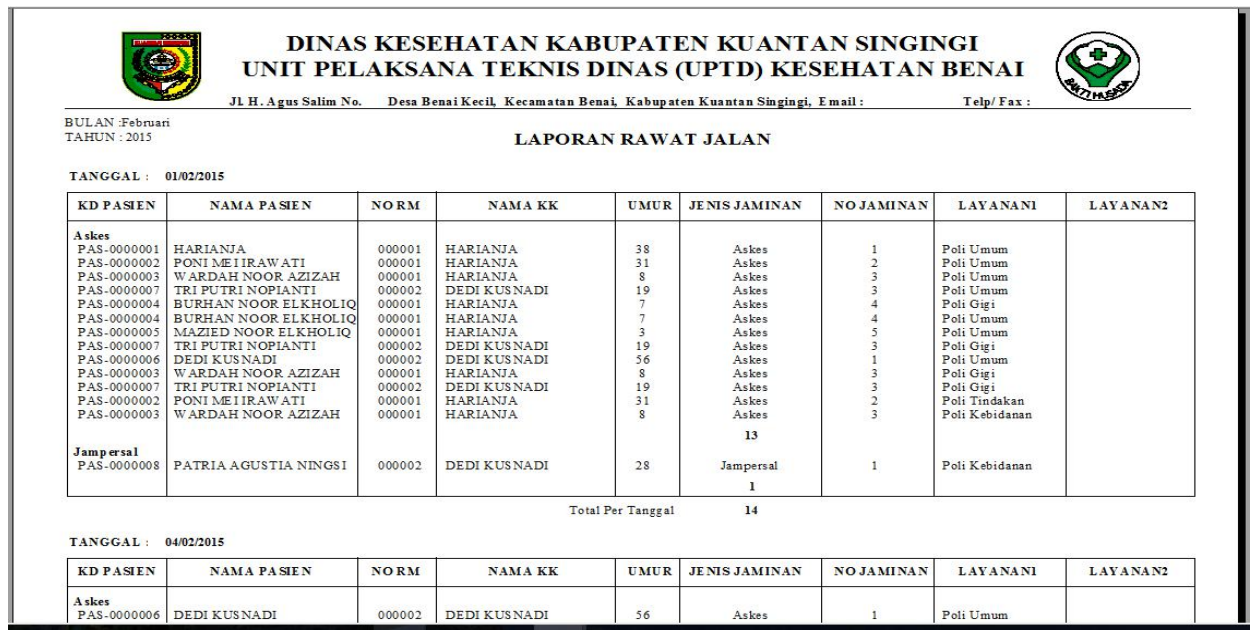

Gambar 4.11. Laporan Rawat Jalan Pertanggal 
3. Laporan Data Rekam Medis

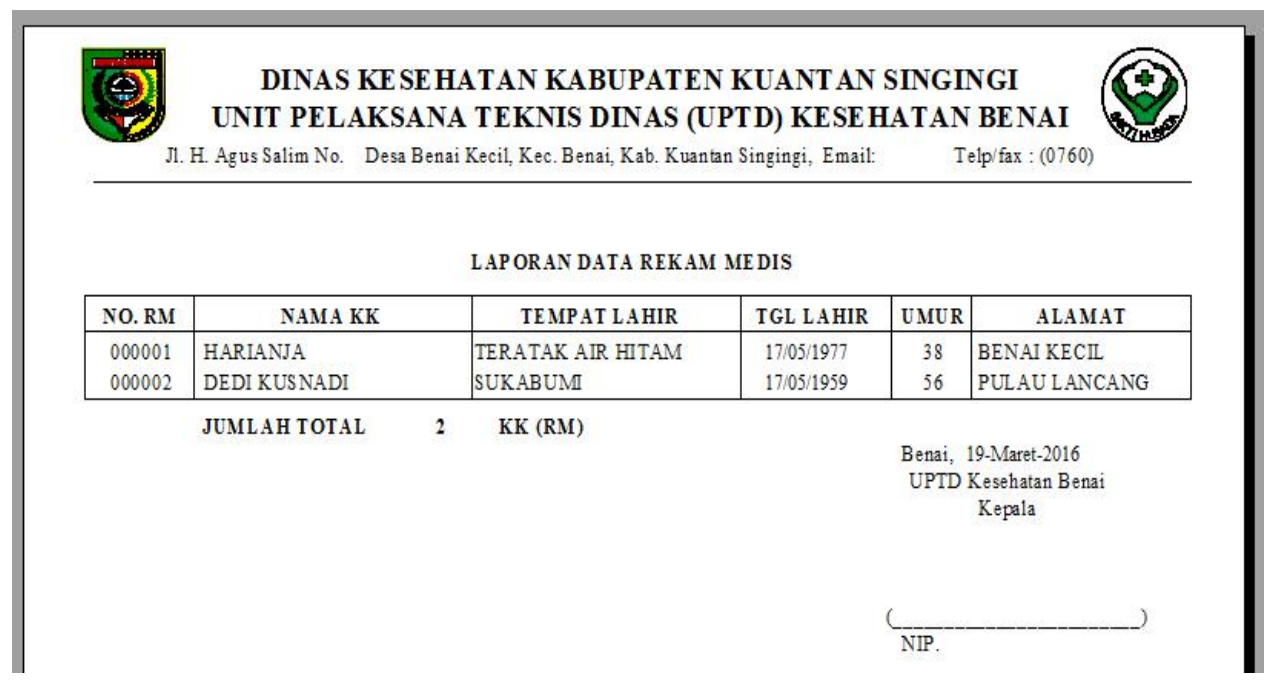

Gambar 4.12. Laporan Data Rekam Medis

4. Lapoaran Data Pasien

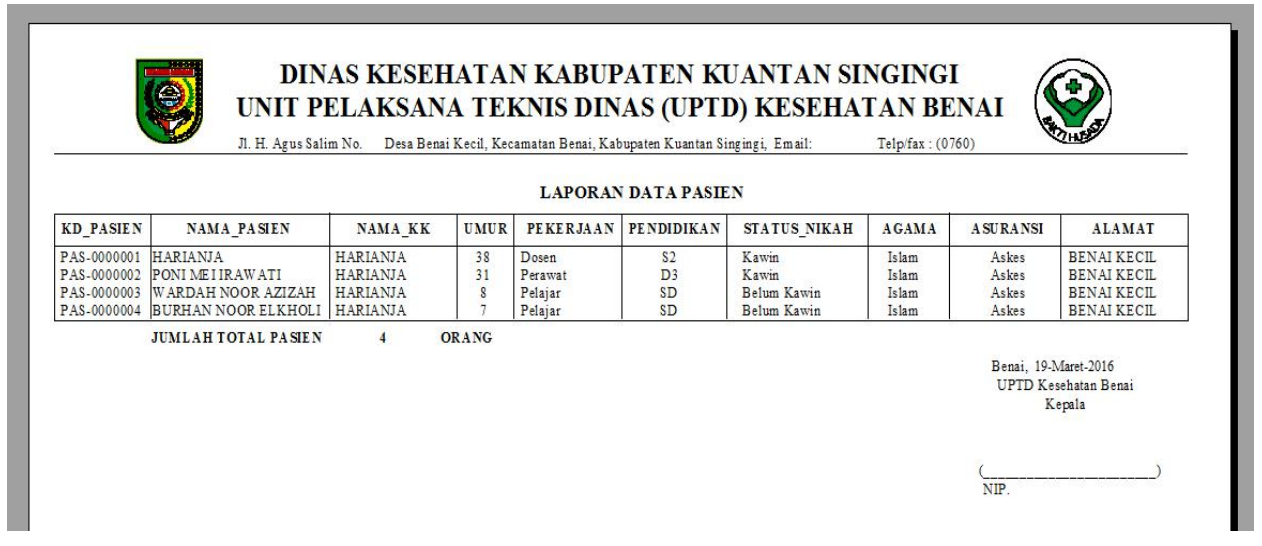

Gambar 4.13. Laporan Data Pasien

\section{KESIMPULAN}

Berdasarkan hasil penelitian dapat disimpulkan bahwa:

1. Dengan aplikasi rawat jalan ini proses registrasi rawat jalan dapat dilakukan dengan cepat sehingga proses penanganan pasien menjadi lebih efektif dan efisien

2. Dengan aplikasi ini proses pembuatan laporan rawat jalan dapat dilakukan dengan sangat mudah dan cepat sehingga memudahkan pihak UPTD dalam pembuatan laporan.

3. Dengan aplikasi ini proses pengarsipan sudah dilakukan di dalam database sehingga, keamanan data relatif lebih terjamin dan proses penyimpanan tidak banyak memakan tempat.

4. Proses pencarian data pasien menjadi lebih cepat jika dibandingkan proses manual.

5. Dengan aplikasi ini, kemungkinan terjadinya data pasien ganda seperti yang sering terjadi pada cara - cara sebelumnya dapat dihindari data. 


\section{DAFTAR PUSTAKA}

Abdul Kadir, 2003, “Database Relasional”, Penerbit Andi Ofset, Yogyakarta.

Abdul Razaq, 2004, "Belajar Cepat Langsung Praktek Visual Basic 6.0”. Penerbit Indah Surabaya.

Harianja, 2012, "Sistem Informasi Klinik Kecantian" Jurnal UNIKS

Janner Simarmata, 2007, "Perancangan Basis Data", Penerbit Andi Offset, Yogyakarta.

Jogiyanto, 2009, “Analisis dan Perancangan Sistem Informasi”, Penerbit Andi Offset, Yogyakarta.

Madcoms, 2002, “Database Visual Basic 6.0 dengan Crystal Reports”, Penerbit Andi, Yogyakarta.

Subari, Yuswanto, 2008, "Pemrograman visual basic 6.0" Cerdas Pustaka Publisher. Jakarta. Suryo Binarto, 2012, "Tip dan Trik Membuat Program Penjualan menggunakan Visual Basic 6.0", Media Kita Jakarta

Tantra, Rudy, 2012, "Manajemen Proyek Sistem Informasi”, Penerbit Andi Offset, Yogyakarta.

Uus Rusmawan, 2002, “Konsep ADO untuk Tugas Akhir dan Skripsi”, Elekmedia Komputindo Jakarta 